\title{
Acetylation of Amino Groups and Its Effect on the Structure of Soybean Glycinin
}

\author{
Fumio Yamauchl, Hidemitsu Ono, Yoshiro Kamata \\ and Kazuo SHIBASAKI \\ Department of Food Chemistry, Faculty of Agriculture, \\ Tohoku University, Sendai \\ Received December 28, 1978
}

\begin{abstract}
Purified soybean glycinin (11S globulin) was acetylated at three degrees; low $(21 \sim 51 \%)$, middle $(60 \sim 81 \%)$ and high $(90 \sim 92 \%)$ acetylation in lysine residues. With increasing the acetyl content, the $\beta$-structure gradually decreased and the random structure increased resulting in the exposure of tyrosine residue. These were determined from the results of optical rotatory dispersion, intrinsic viscosity, ultraviolet and fluorescence measurement. Gel filtration, ultracentrifugation and gel electrophoresis studies showed drastic conformational changes of highly acetylated $11 \mathrm{~S}$ (over $90 \%$ ), in which most of the modified protein $(75 \%)$ polymerized, and the other dissociated into $3 \mathrm{~S}$ protein. The close relation between the conformation of acetylated $11 \mathrm{~S}$ and its emulsifying properties was discussed.
\end{abstract}

Recently, studies on the functional properties of soybean protein have been growing, because the protein is a useful ingredient in the manufacture of processed food. However, there is little information concerning the relationship between the basic protein structure and the functional behavior.

In a previous work ${ }^{11}$ the emulsifying properties of acetylated soybean proteins have been measured. Acid precipitated protein, $7 \mathrm{~S}$ and $11 \mathrm{~S}$ globulin were modified by low $(30 \%)$, middle $(60 \%)$ and high $(90 \%)$ degrees of acetylation. As the acetyl contents of modified $7 \mathrm{~S}$ increased, the emulsifying capacity and the emulsion stability became higher. These properties of modified $11 \mathrm{~S}$ increased with increasing modification until the extent of acetylation became middle degree. However, the high acetylation of this protein gave the remarkable decrease-effects on the emulsifying properties. Interest in this phenomenon led us to study on the molecular structure of the modified $11 \mathrm{~S}$ with varying acetyl content.

Soybean proteins have been modified by various chemical reactions including carboxymethylation, ${ }^{2)}$ deamination, ${ }^{3)}$ succinylation $^{4)}$ and acetylation., ${ }^{4,5}$ These modified proteins were also tested for some functional properties in their reports. However, these reactions have been applied to a heterogeneous protein mixture. Further, some chemical reactions may provide too drastic changes for the structure of the protein to understand the relation between functional properties and the chemical structure, because in these cases many factors affect the structure. Among the chemical reactions, the acetylation can selectively modify the $\varepsilon$-amino group in lysine residues in a mild condition without any side reactions.

The purpose of this research is to investigate the effect of acetylation on the molecular structure of purified $11 \mathrm{~S}$ protein, and the relation between the change of molecular structure and emulsifying properties is discussed.

\section{MATERIALS AND METHODS}

Defatted soybean meal. Soybean (var. Raiden) harvested in 1974 grown at Motoyoshi, Miyagi was dehulled, flaked, defatted with hexane, and ground further in a coffee mill to pass through 40 -mesh sieves.

Preparation of $11 S$ globulin. Defatted soybean meal was agitated with $0.03 \mathrm{~m}$ Tris- $\mathrm{HCl}$ buffer $(\mathrm{pH} 8.0)$ containing $0.01 \mathrm{M}$ 2-mercaptoethanol (ME) (meal: the buffer, $1: 20)$ for $1 \mathrm{hr}$ and centrifuged $(10,000 \mathrm{rpm}$, for $20 \mathrm{~min}$ at $20^{\circ} \mathrm{C}$ ) to obtain buffer extract. The extract was adjusted to $\mathrm{pH} 6.4$ with $2 \mathrm{~N} \mathrm{HCl}$ and stirred 
for $1 \mathrm{hr}$ at $5^{\circ} \mathrm{C}^{\theta\}}$ The suspension was centrifuged $\left(10,000 \mathrm{rpm}, 20 \mathrm{~min}\right.$ at $\left.5^{\circ} \mathrm{C}\right)$ to precipitate the $11 \mathrm{~S}$ protein and washed with $0.01 \mathrm{M}$ Tris- $\mathrm{HCl}$ buffer ( $\mathrm{pH}$ 6.4) three times.

The crude 11S was purified on a column $(5.5 \times 50 \mathrm{~cm})$ of DEAE-Sephadex A-50 equilibrated with $0.035 \mathrm{M}$ phosphate buffer ( $\mathrm{pH} 7.8$ ) containing $0.1 \mathrm{M} \mathrm{NaCl}$ and $0.01 \mathrm{M} \mathrm{ME}$. Elution with $\mathrm{NaCl}$ in gradient concentration of 0.1 to $0.7 \mathrm{M}$ was carried out using a mixer chamber (containing 2 liter of the equilibrated buffer) and a reservoir chamber (containing 2 liter of the phosphate buffer made $0.7 \mathrm{M}$ in $\mathrm{NaCl}, \mathrm{pH} 7.8$ ). The protein in the main peak from the column was dissolved in the phosphate buffer (standard buffer, $2.6 \mathrm{~mm}$ $\mathrm{KH}_{2} \mathrm{PO}_{4}, 32.5 \mathrm{mM} \mathrm{K} \mathrm{HPO}_{4}, 0.4 \mathrm{M} \mathrm{NaCl}, 0.01 \mathrm{M} \mathrm{ME}$, $\mathrm{pH} 7.6, \mu=0.5$ ) and to this solution ammonium sulfate was added until $51 \%$ saturation. The supernatant was adjusted to $66 \%$ saturation with ammonium sulfate and the precipitate was dissolved in the standard buffer ( $\mathrm{pH} 7.6, \mu=0.5$ ). This purified $11 \mathrm{~S}$ showed a single peak in ultracentrifugal analysis as shown in Fig. 6. The protein concentration was measured by the dry weight method after dialysis against water and lyophilization, or ultraviolet spectrum measurement at $280 \mathrm{~nm}$.

Acetylation of $11 S$ protein. The purified 11 S protein was acetylated according to the methods of Ansari et al. $\left.{ }^{7}\right)$ Proteins were dissolved $(1 \%)$ in the standard buffer $(\mathrm{pH} 7.6, \mu=0.5)$ at $0 \sim 4^{\circ} \mathrm{C}$ with constant stirring. Acetic anhydride was added in small aliquots and the $\mathrm{pH}$ of the reaction mixture was maintained between $7.4 \sim 7.8$ by the addition of $1 \sim 2.5 \mathrm{~N} \mathrm{NaOH}$ using a pH stat. The reaction was carried out for $30 \mathrm{~min}$, and then the solution was dialyzed against half-saturated sodium acetate solution and distilled water. In the case of $11 S$, the prolonged dialysis against water sometimes gave some protein precipitation. Therefore, after short time dialysis (1 hr) against water, the solution was dialyzed against the standard buffer $(\mu=0.3$ ) containing $0.2 \mathrm{M} \mathrm{NaCl}$ instead of $0.4 \mathrm{M}$ described above. This solution was used throughout the following experiments.

Determination of extent of chemical modification. TNBS (2, 4, 6-trinitrobenzene 1-sulfonic acid) method ${ }^{83}$ was used to quantify the extent of chemical modification. Sodium borate solutions $(0.15 \mathrm{M}, 2 \mathrm{ml})$ were added to a protein solution $(0.5 \mathrm{ml})$. After addition of a mixture $(1 \mathrm{ml})$ of $0.01 \mathrm{M} \mathrm{Na}_{2} \mathrm{SO}_{3}$ and $0.10 \%$ TNBS (1: 1 , by volume), the solution was kept at $37^{\circ} \mathrm{C}$ for $2 \mathrm{hr}$ and the absorbance was determined at $420 \mathrm{~nm}$. The slopes, $m$ and $m^{\prime}$, for native and modified protein preparations may be related to percent modification by the expression:

$$
\text { Percent modification }=100\left(1-m^{\prime} / m\right)
$$

\section{Ultraviolet (UV)}

spectrum measurements were made in $10 \mathrm{~mm}$-silica cells by a Hitach Model-124 automatic recording spectrophotometer in the wave length range of 250 $310 \mathrm{~nm}$. UV difference spectrum measurements were carried out by the same spectrophotometer with reference to the native protein.

Fluorescence measurements. The excitation and emission fluorescence spectra of the proteins were recorded with a Hitach Model-204 spectrophotofluorometer.

Optical rotatory dispersion (ORD) analysis. ORD of the $300 \sim 600 \mathrm{~nm}$ region was measured. The sample solutions in the standard buffer $(\mu=0.3)$ and a cell of 10-mm path length were used, and the resulting data were treated by means of Moffitt-Yang equation. ${ }^{\text {? }}$

$$
\left[m^{\prime}\right]_{\lambda}=\frac{3}{n^{2}+2} \cdot \frac{M}{100} \cdot \alpha=\frac{a_{0} \lambda_{0}{ }^{2}}{\lambda^{2}-\lambda_{0}{ }^{2}}+\frac{b_{0} \lambda_{0}{ }^{4}}{\left(\lambda^{2}-\lambda_{0}{ }^{2}\right)^{2}}
$$

in which $\left[\mathrm{m}^{\prime}\right]_{2}$ is the mean residue rotation at the wave length of $\lambda$ corrected for the refractive index $(n)$ of solvents, $\lambda_{0}$ is the absorption wave length associated with the rotation assumed to be $212 \mathrm{~nm}$, and $M_{0}$ is the mean molecular weight. The parameter $a_{0}$ and $b_{0}$ were calculated from the intercepts and slopes of $\left[m^{\prime}\right] \lambda \cdot\left(\lambda^{2}-\right.$ $\left.\lambda_{0}{ }^{2}\right)^{-1}$ vs. $\left(\lambda^{2}-\lambda_{0}{ }^{2}\right)^{-1}$ plots. Contents of $\beta$-structure $\left(x^{\beta}\right)$ and $\alpha$-helix $\left(x^{H}\right)$ were calculated from the following equation. ${ }^{10)}$

$$
\begin{gathered}
x^{\beta}=\left(a_{0}+560+1.1 \cdot b_{0}\right) / 800 \\
x^{H}=b_{0} /-630
\end{gathered}
$$

Gel filtration. Protein solutions $(1 \mathrm{ml}, 2 \%)$ were applied on a column of Litex 10 (Litex Co., the molecular range, $10,000 \sim 300,000$ ) and eluted with the standard buffer $(\mu=0.3)$ in $3 \mathrm{ml}$ fractions, which were monitered at $280 \mathrm{~nm}$.

Reduced viscosity. Viscosity was measured by using an Uberode viscometer at $30 \pm 0.01^{\circ} \mathrm{C}$ in the phosphate standard buffer $(\mu=0.3)$.

Sedimentation analysis. Ultracentrifugal analysis was performed with a Hitachi UCA-1A centrifuge at $55,430 \mathrm{rpm}$. Proteins were dissolved in the standard buffer at ionic strength $\mu=0.3$.

Polyacrylamide gel electrophoresis. Gel electrophoresis was carried out in $7.5 \%$ polyacrylamide gels using a slab gel apparatus $(15 \times 12 \mathrm{~cm})$ with the discontinuous buffer system according to Ornstein and Davis. ${ }^{11,12)}$

\section{RESULTS}

\section{Extent of chemical modification}

Figure 1 shows the degree of $\mathrm{N}$-acetylation 


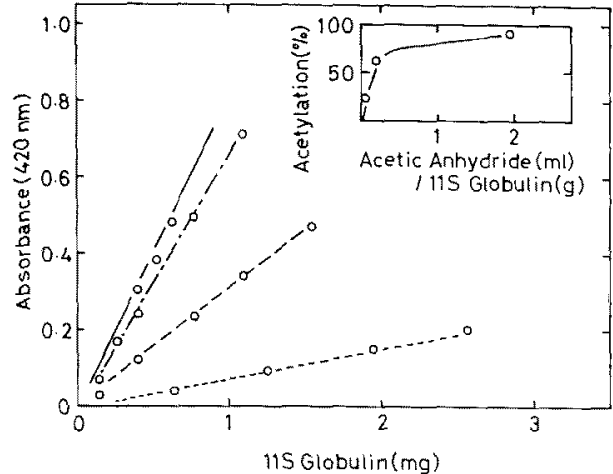

Frg. 1. Determination of Acetyl Content in Soybean 11S Protein.

Lysine residues in $11 \mathrm{~S}$ protein were determined by the TNBS method. Native $11 \mathrm{~S}$ (-), 21\% Ac-11S (- - ), 60\% Ac-11S (---) and 90\% Ac-11S (-..--). The inset shows the amount of acetic anhydride.

TAble I. Relation Between the Amount of ACETIC AnHydride and Extent of Modification AND EXTINCTION COEFFICIENT.

\begin{tabular}{cccl}
\hline $\begin{array}{l}\text { Anhydride } \\
\text { (ml/g } \\
\text { protein) }\end{array}$ & $\begin{array}{c}\text { Modifi- } \\
\text { tion } \\
(\%)\end{array}$ & $E_{280 n m}^{1 \%}$ & Abbreviations \\
\hline 0 & 0 & 8.04 & N-11S \\
0 & 0 & 8.02 & $0 \%$ Ac-11S \\
0.05 & 21 & 8.02 & $21 \%$ Ac-11S \\
0.17 & 60 & 7.90 & $60 \%$ Ac-11S \\
1.91 & 90 & 6.62 & $90 \%$ Ac-11S \\
\hline
\end{tabular}

a The abbreviations used are as follows: $\mathrm{N}-11 \mathrm{~S}$, native $11 \mathrm{~S}$ protein; $n \%$ Ac- $11 \mathrm{~S}, n \%$ acetylated $11 \mathrm{~S}$ protein.

${ }_{b}$ Prepared by the same acetylation procedure without acetic anhydride in the reaction.

caused by treatment of the protein with increasing amounts of acetic anhydride. The extent of modification is given in Table $\mathrm{I}$. Three kinds of acetylated protein were prepared; low $(21 \%)$, middle $(60 \%)$ and high $(90 \%)$ acetyl content. Under the acetylation condition of Ansari et al., ${ }^{7}$ only lysine residues would be modified, since concentrated acetate ions in dialysis solution hydrolyze $O$-acetyl residues. The abbreviations of these modified proteins are shown in Table I. The modified protein, $0 \%$ Ac-11S means the product prepared by the same acetylation procedure and dialysis without acetic anhydride in the reac- tion. The another preparations of $25,51,81$ and $92 \%$ Ac-11S were used for the studies of intrinsic viscosity and gel electrophoresis.

\section{UV Spectra}

The ultraviolet absorption changes caused by acetylation of $11 \mathrm{~S}$ protein are shown in Fig. 2. Acetylation produces a slight change in the absorbance at low and middle acetyl contents, and a significant change is observed at high acetyl content of $11 \mathrm{~S}$ protein. The decrease at $280 \mathrm{~nm}$ is $17.7 \%$ for $90 \%$ Ac- $11 \mathrm{~S}$ (Table I). For $90 \%$ Ac-11S, the absorption maximum shows a blue shift. The difference spectra are shown in Fig. 2. The spectra give negative peaks near 278 and $286 \mathrm{~nm}$ at high acetyl content. In most proteins, negative peaks at 278 and $286 \mathrm{~nm}$ are ascribed to an exposure of tyrosine residues from a hydrophobic region. Therefore, the highly acetylated proteins expose the tyrosine residues from the burried region in the molecule. Negative peaks at 292 and $284 \mathrm{~nm}$ are ascribed to increased hydrophilic circumstances of tryptophan, whereas the acetylated proteins showed no peak at $292 \mathrm{~nm}$, which is specific for tyrptophan.

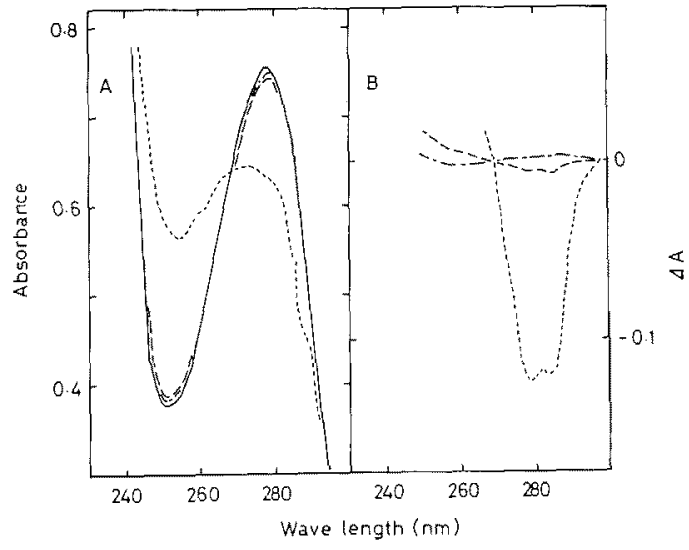

FIG. 2. Ultraviolet Absorption Spectra (A) and Difference Spectra (B) of Native and Acetylated 11S Proteins.

Sample $(0.09 \%)$ were dissolved in the phosphate buffer ( $\mathrm{pH} 7.6, \mu=0.3$ and $0.01 \mathrm{M} 2$-mercaptoethanol). Difference spectra were measured with reference to the native protein. Native $11 \mathrm{~s}$ (-), 21\% Ac-11s (- - ), 60\% Ac-11S (--) and 90\% Ac-11S (-..-). 


\section{Fluorescence spectra}

The excitation and emission spectra of $11 \mathrm{~S}$ protein and various acetylated 11S are shown in Fig. 3. The quantum yield of $11 \mathrm{~S}$ increased with increasing acetyl content, appreciably for $90 \%$ Ac-11S. The emission maximum for $90 \%$ Ac- $11 \mathrm{~S}$ shows a small (about $2 \mathrm{~nm}$ ) red shift. These results suggest a very little change of environment of tryptophan or some other residues in the modified proteins.

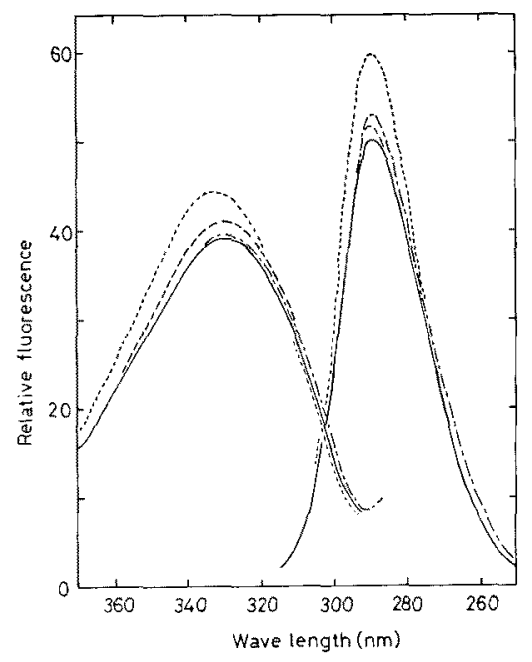

FIG. 3. Excitation and Emission Spectra of Native and Acetylated 11S Proteins.

Samples $(0.09 \%)$ were dissolved in the phosphate buffer ( $\mathrm{pH} 7.6, \mu=0.3$ and $0.01 \mathrm{~m} 2$-mercaptoethanol). Left: emission spectra (excitation wavelength is 280 $\mathrm{nm}$ ). Right: excitation spectra (emission wavelength is $335 \mathrm{~nm})$. Native $11 \mathrm{~S}(-), 21 \%$ Ac-11S (- $)$, $60 \%$ Ac-11S (--) and $90 \%$ Ac-11S (-----).

\section{Optical rotatory dispersion}

ORD was measured to determine the secondary structure of the acetylated proteins. The results in Fig. 4 show a decrease of $\beta$-structure and an increase of random structure with increase of acetyl content. However, $\alpha$-helix does not change appreciably. The contents of $\beta$-structure, $\alpha$-helix and random structure changed from 40,6 , and $55 \%$ for native to 24,8 , and $68 \%$ for $90 \%$ Ac-11S, respectively.

\section{Gel filtration}

Figure 5 shows the elution patterns of the native and acetylated $11 \mathrm{~S}$ proteins. For 21

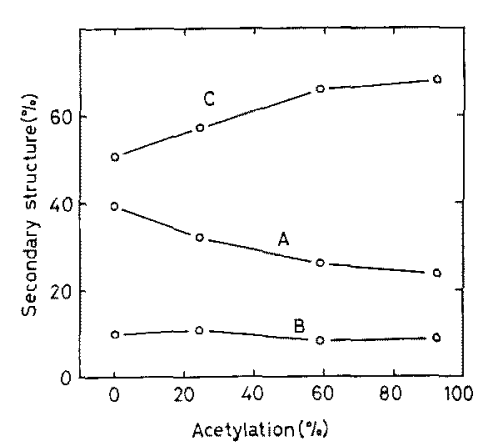

FIg. 4. Effect of Acetylation on the Secondary Structure of Acetylated 11S Proteins.

Samples $(0.3 \%)$ were dissolved in the phosphate buffer (pH 7.6, $\mu=0.3$ and $0.01 \mathrm{M}$ 2-mercaptoethanol). The contents of secondary structure were calculated from the ORD parameters. A, $\beta$-structure; $B, \alpha$ helix; $C$, random structure.

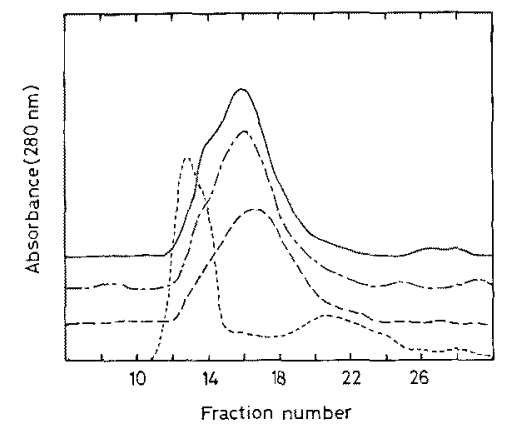

FIG. 5. Chromatogram of Native and Acetylated $11 \mathrm{~S}$ Proteins by Gel Filtration.

A column (Litex 10, $1 \times 110 \mathrm{~cm}$ ) was eluted with the phosphate buffer (pH 7.6, $\mu=0.3$ and $0.01 \mathrm{~m} 2$ mercaptoethanol) in $3 \mathrm{ml}$ fractions. Native $11 \mathrm{~S}$ $(-), 21 \%$ Ac- $11 \mathrm{~S}(--), 60 \%$ Ac-11S (--) and $90 \%$ Ac-11S (-..-.).

and $60 \%$ Ac- $11 \mathrm{~S}$, the main peaks become more broad. Pronouncedly, different from the others, the main peak for $90 \%$ Ac-11S moves to the position of the void volume, accompanied with a little peak at the latter position. These indicate that the most of $90 \%$ Ac- $11 \mathrm{~S}$ (75.3\% for fraction number $11 \sim 16$ based on the UV measurement) polymerizes and the some other part $(24.7 \%$ for fraction number $19 \sim 24$ ) dissociates.

\section{Ultracentrifugation}

Ultracentrifugal analyses of the native and 


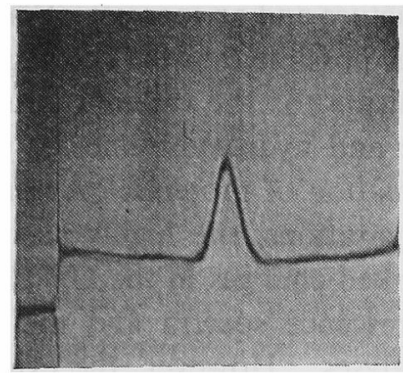

A

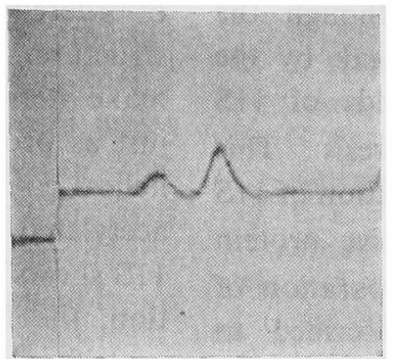

$B$

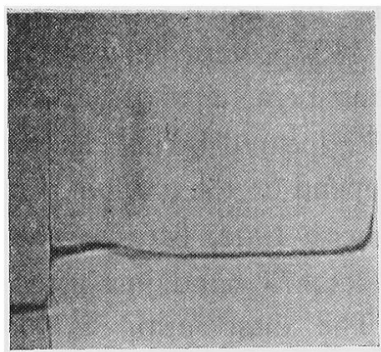

C

Fig. 6. Ultracetrifugal Patterns of Native 11S (A), 60\% Ac-11S (B) and 90\% Ac-11S (C). Samples $(1.0 \%$ ) were dissolved in the phosphate buffer ( $\mathrm{pH} 7.6, \mu=0.3$ and 0.01 м 2-mercaptoethanol). Photographs were taken at $45 \mathrm{~min}$ after reaching $55,430 \mathrm{rpm}$.

acetylated proteins are shown in Fig. 6. Native $11 \mathrm{~S}$ protein shows a single peak. The sedimentation pattern of $60 \%$ Ac-11S gives the

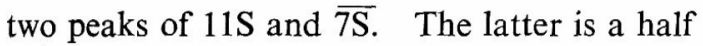
molecule of $11 \mathrm{~S}$, and this agrees with the fact that the main peaks become broad in gel filtration pattern. For $90 \%$ Ac- $11 \mathrm{~S}, \overline{7 \mathrm{~S}}$ disappears and a little $3 \mathrm{~S}$ peak appears and the most of the modified protein moves to the bottom. These indicate the polymerization.

\section{Reduced viscosity}

Viscosity data of the native and the modified proteins are shown in Fig. 7. For $51 \% \mathrm{Ac}-11 \mathrm{~S}$

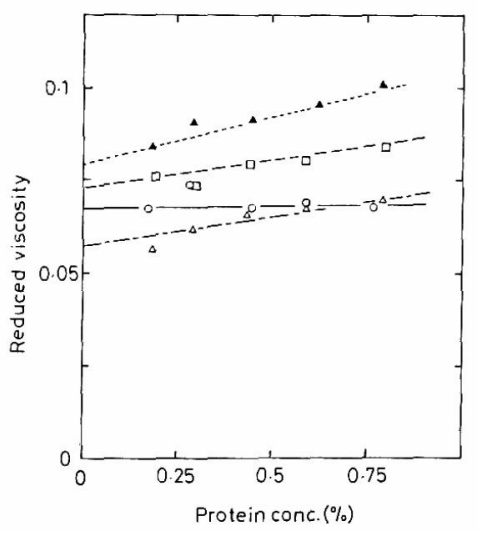

FIG. 7. Reduced Viscosity of Native and Acetylated 11S Proteins.

Viscosity was measured with an Uberode viscometer at $30 \pm 0.01^{\circ} \mathrm{C}$ in the phosphate buffer $(\mathrm{pH} 7.6, \mu=$ 0.3 and $0.01 \mathrm{~m}$ 2-mercaptoethanol). Native $11 \mathrm{~S}$ (-), 51\% Ac-11S (- - ), 81\% Ac-11S (--) and $92 \% \mathrm{Ac}-11 \mathrm{~S}(----)$. a little decrease is shown and $91 \%$ Ac-11S gives a definite increase than native $11 \mathrm{~S}$. The decrease of the viscosity for $51 \%$ Ac- $11 \mathrm{~S}$ may be ascribed to dissociation to $\overline{7 \mathrm{~S}}$ and the increase for $91 \%$ Ac-11S may depend on the polymerization, which is suggested by the results of gel filtration, ultracentrifugation, and gel electrophoresis.

\section{Gel electrophoresis}

Figure 8 shows the slab gel electrophoresis
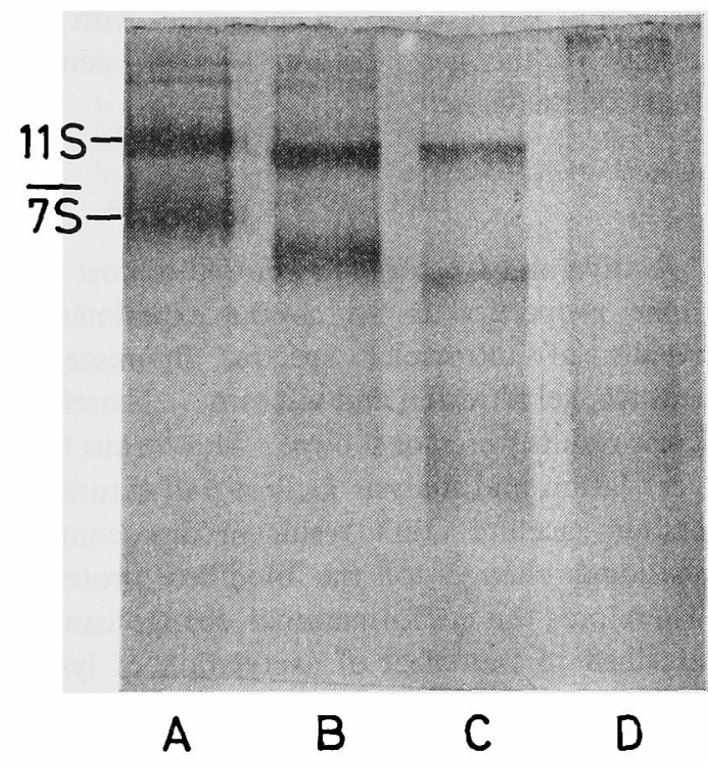

FIG. 8. Slab Gel Electrophoretic Patterns of Native and Acetylated 11S Proteins.

Slab gel $(15 \times 12 \mathrm{~cm})$ was run in $7.5 \%$ polyacrylamide gel with the discontinuous buffer system of Davis. Native 11S (A), 25\% Ac-11S (B), 60\% Ac-11S (C) and $92 \%$ Ac-11S (D). 
patterns by Davis's system. Although the native $11 \mathrm{~S}$ protein showed one peak by the ultracentrifugal analysis, two bands of $11 \mathrm{~S}$ and $\overline{7 S}$ appeared by gel electrophoresis. This may depend on the gradual dissociation of $11 \mathrm{~S}$ to $\overline{7 \mathrm{~S}}$ with time, because the native protein shows less $\overline{7 \mathrm{~S}}$ band just after preparation of 11S. The dissociation is also ascribed to electrophoretic conditions of Davis's system which has lower ionic strength and higher $\mathrm{pH}$ than those of the stable conditions of 11S.

The electrophoretical mobility of a protein in gel depends on the net charge and size of the protein molecule. Upon acetylation ammonium cations are replaced by neutral acetyl groups which provide an increase of the more net anions in the molecule. This agrees with the mobility of acetylated proteins from native to $60 \% \mathrm{Ac}-11 \mathrm{~S}$, where the higher acetyl contents showed the higher mobility with respect to the $11 \mathrm{~S}$ and $\overline{7 \mathrm{~S}}$ band. The band of $7 \mathrm{~S}$ moved at higher rate than that of $11 \mathrm{~S}$. The $\overline{7 \mathrm{~S}}$ seemed to be acetylated more easily than 11S. For $91 \%$ Ac-11S, the presence of polymerized protein at starting line and dissociated protein at the fast moving end agrees with the results of the gel filtration and the centrifugation analyses.

\section{DISCUSSION}

Native and $0 \% \mathrm{Ac}-11 \mathrm{~S}$ showed almost the same properties as far as the experimental results of ultraviolet spectra, fluorescence spectra, gel filtration and viscosity. Therefore these results were not shown. This means that acetylation and dialysis against half-saturated sodium acetate don't result in any conformational changes of the modified proteins. Therefore, the conformational change can be ascribed to the effect of acetylation of lysine residues in $11 \mathrm{~S}$ protein.

For acetylated $11 \mathrm{~S}$ preparations, UV and fluorescence measurements show the gradual conformational changes with the extent of acetyl content, significant at high acetylation, resulting in the exposure of tyrosine residues. ORD measurement shows a gradual decrease of ordered structure and an increase of random structure. It is possible that the acetyl groups make steric misfits for the ordered structure, just as proline and hydroxyproline for the $\alpha$ helical conformation of proteins. Among the acetylated preparations, the highly acetylated 11S shows marked changes in the UV absorption, the fluorescence spectra and the ultracentrifugal analyses. However, the extent of the conformational change of the highly acetylated $11 \mathrm{~S}$ is far less than that of denatured 11S with $8 \mathrm{M}$ urea. Fukushima ${ }^{13)}$ reported that the $11 \mathrm{~S}$ changes the parameter, $-a_{0}$, from 290 to 540 in $8 \mathrm{M}$ urea, whereas the highly acetylated protein changed the $-a_{0}$ from 205 for the native protein to 312 . Therefore, the different value in the change is 250 for $8 \mathrm{M}$ urea denaturation and 107 for $90 \%$ acetylation. However, drastic changes are observed in the molecular size of acetylated $11 \mathrm{~S}$ by means of gel filtration, ultracentrifugation, intrinsic viscosity and gel electrophoresis. The half molecule of $11 \mathrm{~S}(\overline{7 \mathrm{~S}})$ is shown at middle acetylation. The high acetylation causes the polymerization of the most of $11 \mathrm{~S}$ accompanied by the dissociation to $3 \mathrm{~S}$.

Recently, we have reported the emulsifying properties of acetylated soybean proteins ${ }^{11}$. As the acetyl contents of modified $7 \mathrm{~S}$ increased, the emulsifying capacity and the emulsion stability became higher. These properties of modified $11 \mathrm{~S}$ increased with increasing modification until the extent of acetylation became middle degree, thereafter decreased. This characteristic decrease consists with the drastic change in the $11 \mathrm{~S}$ molecular size by the polymerization and a little dissociation. The increased emulsifying activity, as much as middle acetyl content, is supposed to depend on the increase of hydrophobic properties of the acetyl group and on the neutralization of ammonium cation. However, the decreased emulsifying properties in high acetylation mean that the emulsifying properties are ascribed to not only the hydrophobic property but also the molecular structure. The polymerization of $11 \mathrm{~S}$ protein causes the decrease of emulsifying properties. The polymerization may reduce the number 
of attaching site of oil. It was reported that the moderate partial hydrolysis of soybean protein with mineral acid or enzyme increased its emulsifying properties. ${ }^{14 \sim 16}$ ? Recent paper has also reported that the dissociation of vegetable proteins with denaturing agents provides greater emulsion stability. ${ }^{17}$ ) This degradation or dissociation seems to be accompanied by an increase of hydrophobic residues.

The subunit structure of 11S may be stabilized by noncovalent interactions such as ionic and hydrogen bonds and hydrophobic interaction, together with the covalent bond of disulfide. The removal of positive charges by high acetylation over $90 \%$ would destroy the molecular structure of $11 \mathrm{~S}$ protein. This is an evidence that the ionic bonds contribute to stabilize the 11S structure. Eleven $\mathrm{S}$ protein consists of acidic and basic subunits, ${ }^{181}$ on the other hand, 7S protein consists of no definite acidic or basic subunits. ${ }^{19}$ Therefore, the high acetylation may affect rather $11 \mathrm{~S}$ than $7 \mathrm{~S}$. This agrees with the fact that the emulsifying properties of highly acetylated 11S showed the lowest value, whereas, highly acetylated $7 \mathrm{~S}$ gave the highest value compared with the preparations of middle or low acetyl content.

\section{REFERENCES}

1) F. Yamauchi, N. Hishinuma, $H$. Ono and $K$.
Shibasaki, Nippon Shokuhin Kogyo Gakkaishi, 25, 446 (1978).

2) L. L. McKinney and E. H. Uhing, J. Am. Oil Chem. Soc., 36, 49 (1959).

3) K. Saio, M. Kajikawa and T. Watanabe, Nippon Shokuhin Kogyo Gakkaishi, 19, 321 (1972).

4) K. L. Franzen and J. E. Kinsella, J. Agric. Food Chem., 24, 788 (1976).

5) B. G. Barman, J. R. Hansen and A. R. Mossey, ibid., 25, 638 (1977).

6) V.H. Thanh and K. Shibasaki, ibid., 24, 1117 (1976).

7) A. A. Ansari, S. A. Kidwai and A. Salahuddin, J. Biol. Chem., 250, 1625 (1975).

8) T. Okuyama and H. Kasai, Tanpakushitsu Kakusan Koso, 18, 1153 (1973).

9) G. D. Fasman, "Method in Enzymology," vol. 6, ed. by S. P. Colowick and N. O. Kaplan, Academic Press, New York, 1963, p. 928.

10) K. Imahori and N. A. Nicola, "Physical Principles and Techniques of Protein Chemistry," Part C, ed. by S. J. Leach, Academic Press Inc., New York, 1973, p. 358.

11) L. Ornstein, Ann. N. Y. Acad. Sci., 121, 321 (1964).

12) B. J. Davis, ibid., 121, 404 (1964).

13) D. Fukushima, Cereal Chem., 45, 203 (1968).

14) H. Aoki and H. Matsuura, Nippon Shokuhin Kogyo Gakkaishi, 23, 26 (1976).

15) H. Aoki, H. Okamura and M. Inami, ibid., 24, 511 (1977).

16) G. Puski, Cereal Chem., 52, 655 (1975).

17) V. B. Kamat, G. E. Graham and M. A. F. Davis, ibid., 55, 295 (1978).

18) K. Kitamura, T. Takagi and K. Shibasaki, Agric. Biol. Chem., 40, 1837 (1976).

19) V.H. Thanh and K. Shibasaki, Biochim. Biophys. Acta, 490, 370 (1977). 